\title{
PERBEDAAN TINGKAT KECEMASAN DALAM PEMILIHAN PASANGAN PADA WANITA TRIWANGSA DEWASA AWAL DI BALI YANG DITINJAU BERDASARKAN POLA ASUH OTORITARIAN
}

\author{
Ida Ayu Ratih Purnama Adi dan David Hizkia Tobing \\ Program Studi Psikologi, Fakultas Kedokteran, Universitas Udayana \\ idaayuratih@gmail.com
}

\begin{abstract}
Abstrak
Indonesia yang memiliki beragam tradisi, budaya dan adat istiadat masih mengganggap pemilihan pasangan merupakan hal yang penting, khususnya bagi masyarakat Bali. Secara tidak langsung, orangtua akan ikut berperan dalam menentukan kriteria pasangan hidup untuk anak-anaknya, terutama terhadap anak perempuan. Peran tersebut dapat tercermin melalui pola asuh yang diterapkan. Orangtua dari kategori triwangsa yaitu wangsa Brahmana, Ksatrya, dan Waisya meyakini bahwa dengan menerapkan pola asuh otoritarian dapat membuat anak patuh dan mampu menerapkan nilai-nilai yang berlaku dalam masyarakat untuk melestarikan wangsa. Anak dengan penerapan pola asuh otoritarian cenderung menggambarkan kecemasan yang disebabkan oleh kontrol yang tinggi dari orangtua agar anak perempuannya mencari wangsa yang sepadan atau lebih tinggi. Penelitian ini bertujuan untuk mengetahui perbedaan tingkat kecemasan dalam pemilihan pasangan pada wanita triwangsa dewasa awal di Bali yang ditinjau berdasarkan pola asuh otoritarian. Subjek dalam penelitian ini adalah 105 wanita triwangsa dewasa awal di Bali yang belum menikah. Subjek dipilih dengan menggunakan teknik cluster sampling. Instrumen dalam penelitian ini adalah skala kecemasan dalam pemilihan pasangan dan skala pola asuh otoritarian. Hipotesis penelitian diuji dengan analisis kovarian. Hasil tersebut menunjukkan bahwa nilai signifikansi sebesar $0,000(p<0,05)$ sehingga dapat disimpulkan bahwa pola asuh otoritarian dan triwangsa memberikan kontribusi terhadap tingkat kecemasan dalam pemilihan pasangan pada wanita triwangsa. Hal tersebut terjadi karena sistem masyarakat Hindu di Bali terkait dengan wangsa masih memiliki pengaruh yang signifikan, sehingga wanita triwangsa akan mendapatkan kontrol dan tuntutan dari keluarga untuk mencari pasangan dari wangsa yang sepadan atau lebih tinggi. Kecemasan dalam memilih pasangan akan timbul ketika wanita triwangsa tidak memenuhi tuntutan dari orangtua untuk memilih pasangan dari wangsa yang sepadan atau lebih tinggi, dalam penelitian ini yang lebih berpengaruh terhadap kecemasan dalam pemilihan pasangan adalah pola asuh otoritarian.
\end{abstract}

Kata kunci: Wanita triwangsa, kecemasan dalam pemilihan pasangan, pola asuh otoritarian.

\begin{abstract}
Indonesia with various traditions, cultures, and mores, still considers partner choosing as an important thing, specially for Balinese people. Parents indirectly play a part in choosing a partner for their children, especially their daughters. Parents from triwangsa category such as wangsa Brahmana, Ksatrya, and Waisya believe that by applying authoritarian parenting style, they are raising obedient children, who will be able to apply the society values to preserve the wangsa. Children from authoritarian families tend to have anxiety that caused by high control from parents and pressure to choose a partner from the same wangsa or higher. This study was conducted to assess the differences in anxiety level in partner choosing in triwangsa women in Bali based on authoritarian parenting style. Subjects in this study using 105 early adult unmarried triwangsa women in Bali. Subjects were selected using cluster sampling technique. Instruments in this study are the scale of anxiety for partner choosing and authoritarian parenting scale. Hypotheses were tested with analysis covariance. The results showed that a significance value of $0.000(p<0.05)$ so that, it summarize that the authoritarian parenting style and triwangsa contributed to the level of anxiety in female partner selection in triwangsa. This happens because Hindus community system in Bali related to the wangsa that still have a significant effect, so triwangsa women will get control and demands from the family to find the partner from equivalent or higher wangsa. Anxiety will emerge when triwangsa women do not accomplish the demands from their parents to choose a partner from the equivalent or higher wangsa. Anxiety in choosing a partner will emerge when a triwangsa women do not meet the demands of parent to choose a partner from a corresponding or higher wangsa, in this study that is more influential on anxiety in the selection of a partner is an authoritarian parenting style.
\end{abstract}

Keywords: Triwangsa women, anxiety in partner choosing, authoritarian parenting. 


\section{LATAR BELAKANG}

Manusia pada dasarnya merupakan makhluk sosial yang tidak dapat hidup sendiri, akan senantiasa membutuhkan orang lain, selalu berinteraksi, saling bersosialisasi maupun bertukar pengalaman serta untuk meneruskan keturunannya. Manusia dalam memenuhi kebutuhan-kebutuhan tersebut harus melalui beberapa tahap perkembangan, salah satunya adalah memasuki masa dewasa awal. Menurut Erickson, masa dewasa awal berada pada tahap intimacy vs isolation, pada masa ini individu menghadapi tugas perkembangan untuk membentuk intimasi dengan orang lain. Bila individu tidak dapat membentuk intimasi dan tidak dapat menjalin komitmen pribadi dengan orang lain, individu akan berisiko menjadi terlalu terisolasi dan terpaku kepada diri sendiri (Santrock, 2009). Selain itu, pada masa dewasa awal, individu juga akan menghadapi tuntutan untuk membentuk suatu keluarga. Tuntutan-tuntutan untuk membentuk keluarga ini berasal dari faktor lingkungan sosial, budaya dan lingkungan, yang kemudian faktor-faktor ini akan memengaruhi pemilihan pasangan, strategi dalam pemilihan pasangan dan keadaan hubungan (Santrock, 2009).

Pemilihan pasangan merupakan proses awal yang harus dilakukan individu sebelum individu memutuskan ke jenjang pernikahan dan membentuk keluarga. Di Indonesia, khususnya pada masyarakat Bali, pemilihan pasangan masih menjadi hal yang sangat penting dalam masyarakatnya. Pentingnya pemilihan pasangan pada masyarakat Bali tidak terlepas dari faktor budaya dan konflik internal yang muncul dari dalam masyarakat Bali itu sendiri. Konflik yang paling sering muncul adalah konflik yang dikaitkan dengan sistem catur wangsa, yang lebih dikenal dengan kasta dan gelar (Wiana, 2006). Wangsa brahmana, wangsa ksatrya, dan wangsa waisya termasuk dalam kategori triwangsa dan Wangsa sudra dikategorikan ke dalam kelompok jabawangsa (Wiana, 2006).

Sistem kekerabatan masyarakat Bali, pada umumnya bersifat patrilineal yang artinya suatu adat masyarakat yang mengatur alur keturunan berasal dari pihak laki-laki, sehingga kedudukan laki-laki terlihat lebih diutamakan (Kompas, 2014). Sistem patrilineal mengharuskan seorang istri mengikuti garis keturunan suami, dan jika terjadi perceraian, maka semua anak-anak akan berada dalam pengasuhan suami, termasuk penyantuman tingkat wangsa. Apabila dikaitkan dengan pemilihan pasangan, wanita Bali tidak hanya terbatas pada perasaan yang dimiliki, tetapi juga harus melihat kelas sosial dan tingkat wangsa pasangan dalam masyarakat. Wanita Bali yang termasuk dalam stratifikasi sosial triwangsa akan memiliki kecenderungan mencari pasangan laki-laki yang berasal dari wangsa yang sepadan atau lebih tinggi, yang bertujuan untuk menjaga kemurnian keturunan (Diantha \& Wisanjaya, 2010).

Menikah dengan pasangan dari wangsa yang lebih rendah masih sangat dihindari, karena wanita yang menikah dengan laki-laki dari wangsa yang lebih rendah akan mengalami proses penurunan kasta atau yang diistilahkan dengan "nyerod" dan akan menyebabkan wanita tersebut kehilangan status triwangsanya, apabila menikah dengan wangsa yang lebih rendah ketika bercerai dan ingin kembali ke rumah asalnya, akan mengalami kondisi yang menekan karena saat akan melakukan pernikahan tanpa meminta restu dari orangtua (Paramitha, 2016), Alasan tersebut membuat keluarga wanita triwangsa tidak mengijinkan anak wanita dari kategori triwangsa untuk menikah dengan laki-laki yang memiliki wangsa yang lebih rendah. Restu orangtua sangat memengaruhi terciptanya pernikahan yang bahagia, tidak hanya dalam pernikahan restu orangtua berlangsung saat anak mulai memutuskan dalam pemilihan pasangan (Adi, 2016).

Secara tidak langsung orangtua juga akan ikut berperan dalam menentukan kriteria pasangan hidup untuk anak-anaknya, termasuk dalam kriteria memiliki pasangan dari wangsa yang sepadan atau yang lebih tinggi. Menurut Purnomo, Natajaya dan Sudiatmika (2014), keterlibatan orangtua sangat berpengaruh dalam proses pemilihan pasangan, keterlibatan ini sudah terjadi ketika anak-anak diberikan ajaran, pengetahuan pemahaman terkait nilai-nilai, dan keyakinan. Keberhasilan orangtua dalam memberikan pengetahuan dan pemahaman tentang wangsa agar sesuai dengan nilai-nilai yang berlaku di masyarakat, sangat dipengaruhi oleh pola pengasuhan orangtua.

Menurut Baumrind (dalam Santrock, 2007b), terdapat beberapa pola asuh yang biasa diterapkan orangtua, salah satu diantaranya adalah pola asuh otoritarian. Pola asuh otoritarian adalah gaya pengasuhan yang membatasi, menghukum, dan menuntut anak untuk mengikuti perintah-perintah orangtua dan menghormati pekerjaan dan usaha, memberikan batasanbatasan yang tegas dan tidak memberi peluang yang besar kepada anak-anak untuk berbicara. Orangtua cenderung berusaha agar anak mengikuti arahan yang diberikan, menjelaskan nilai-nilai yang berlaku didalam masyarakat, jika dikaitkan dengan wangsa, masyarakat Bali dari kategori triwangsa menginginkan agar anaknya mampu untuk melestarikan wangsa, sehingga orangtua dari kategori triwangsa menanamkan nilai-nilai dan keyakinan terhadap anak untuk melestarikan wangsa. Nilai-nilai merupakan seperangkat keyakinan dan sikap bagaimana sesuatu itu seharusnya (Santrock, 2007a).

Orangtua dari kategori triwangsa meyakini dengan memberikan penerapan pola asuh otoritarian, merupakan cara yang terbaik agar anak patuh dan mampu menerapkan nilainilai yang berlaku dalam masyarakat untuk melestarikan wangsa. Hasil studi pendahuluan yang dilakukan oleh peneliti, memperoleh hasil bahwa 20 dari 30 subjek kategori triwangsa memperoleh penerapan pola asuh otoritarian, subjek diberikan batasan-batasan dalam setiap hal yang dilakukan, dituntut agar sesuai dengan arahan orangtua, kontrol yang tegas dan setiap keputusan yang akan diambil harus berdasarkan izin dari orangtua subjek. Penerapan pola asuh otoritarian memberikan 
dampak yang berbeda-beda pada subjek dari kategori triwangsa, seperti merasakan kecemasan karena khawatir jika orangtua tidak memberikan restu kepada pasangan yang dimiliki, takut apabila tidak menemukan pasangan dengan kasta sepadan atau yang lebih tinggi, gelisah, bimbang, merasa malu, dan merasa turunnya harga diri sebagai wanita yang berkasta (Adi, 2016).

Kecemasan adalah suatu perasaan takut dan khawatir yang tidak menyenangkan (Davison, Neale, \& Kring, 2004). Selain itu, Menurut Hawari (2013) kecemasan merupakan gangguan dalam perasaan yang ditandai dengan perasaan ketakutan atau kekhawatiran yang mendalam dan berkelanjutan, namun tidak mengalami gangguan dalam menilai realitas, kepribadian masih tetap utuh, perilaku dapat terganggu tetapi masih dalam batas normal. Kecemasan yang difokuskan dalam penelitian ini adalah kecemasan dalam pemilihan pasangan. Gangguan kecemasan juga dapat diartikan sebagai gangguan psikologis, meliputi ketegangan motorik (bergetar, tidak mampu duduk tenang, tidak mampu bersantai); hiperaktivitas (pusing, jantung yang berdetak cepat dan berkeringat); serta harapan-harapan yang dirasakan dan pikiran mendalam yang dialami oleh individu (King, 2010).

Berdasarkan pemaparan diatas, orangtua dari kategori triwangsa menginginkan anaknya memperoleh pasangan yang berasal dari wangsa yang sepadan atau lebih tinggi, karena orangtua cenderung baranggapan bahwa memiliki pasangan dari wangsa yang sepadan atau lebih tinggi merupakan hal terbaik untuk anak-anaknya guna melestarikan wangsa. Orangtua akan cenderung menerapkan pola asuh otoritarian agar anak-anak dari kategori triwangsa berperilaku sesuai dengan apa yang diharapkan orangtua, khususnya dalam pemilihan pasangan. Pola asuh otoritarian akan membatasi serta mengarahkan perilaku anak-anak yang kemudian berdampak pada munculnya kecemasan pada wanita triwangsa saat memilih pasangan. Oleh karena itu, peneliti tertarik untuk mengetahui lebih bagaimana perbedaan tingkat kecemasan dalam pemilihan pasangan pada wanita triwangsa dewasa awal di Bali yang ditinjau berdasarkan pola asuh otoritarian.

\section{METODE PENELITIAN}

\section{Hipotesis Penelitiam}

Terdapat hipotesis mayor dan minor dalam penelitian ini yaitu untuk hipotesis mayor apakah ada perbedaan tingkat kecemasan dalam pemilihan pasangan pada wanita triwangsa dewasa awal yang dikontrol pola asuh, sedangkan untuk hipotesis minor dalam penelitian ini ingin membuktikan apakah terdapat perbedaan pola asuh otoritarian jika ditinjau dari triwangsa serta apakah pola asuh otoritaria berperan dalam pemilihan pasangan pada wanita triwangsa.

\section{Variable dan Definisi Operational}

Penelitian ini menggunakan tiga buah variabel yaitu triwangsa sebagai variabel bebas, kecemasan dalam pemilihan pasangan sebagai variabel tergantung dan pola asuh otoritarian sebagai kovariabel. Adapun definisi operasional dari masingmasing variabel penelitian ialah sebagai berikut:

Definisi operasional Kecemasan merupakan suatu perasaan takut dan khawatir yang tidak menyenangkan, yang juga dapat diartikan sebagai gangguan yang meliputi gejala fisik, gejala afektif, gejala kognitif. Kecemasan dalam penelitian ini dilihat pada kecemasan dalam pemilihan pasangan, yang timbul akibat pengaruh dari pola asuh otoritarian yang diberikan orangtua, yang mengharuskan wanita dari kategori triwangsa menikah dengan wangsa yang sepadan atau yang lebih tinggi agar tidak "nyerod" dan menghilangkan status triwangsanya. Tingkat kecemasan diukur dengan skala kecemasan dalam pemilihan pasangan yang disusun berdasarkan mengelompokkan tipe kepribadian dan gejala klinis menurut Hawari (2013), yang disebutkan menjadi menjadi 3 dimensi.

Definisi operasional Pola asuh otoritarian merupakan pola asuh yang berusaha agar anak mengikuti pengarahan yang diberikan, kontrol yang tinggi, menghormati pekerjaan serta usaha-usaha yang telah dilakukan, dan kurang memberikan peluang bagi anaknya untuk berdialog secara verbal bahkan berdiskusi untuk penyelesaian masalah. Pola asuh otoritarian diukur menggunakan skala pola asuh otoritarian yang disusun berdasarkan enam aspek pola asuh otoritarian menurut Cross (2009).

Definisi operasional Triwangsa merupakan urutan tiga teratas dari Catur Wangsa, yaitu wangsa Brahmana, wangsa Ksatrya, dan wangsa Waisya (Wiana, 2006). Identitas Triwangsa tersebut dapat dilihat pada nama lengkap subjek penelitian, misalnya Ida Ayu merupakan keturunan dari wangsa Brahmana, Cokorda Istri, Anak Agung Istri, I Dewa Ayu, Desak, Sang Ayu merupakan keturunan dari wangsa Ksatrya, serta Ni Gusti Ayu, Gusti Ayu merupakan keturunan dari wangsa Waisya ( Panetje, 2004).

\section{Responden}

Populasi dalam penelitian ini adalah wanita triwangsa dewasa awal di Bali. Subjek dalam penelitian ini adalah wanita triwangsa dewasa awal di Bali yang belum menikah dan bersedia menjadi subjek penelitian. Teknik pengambilan sampel dalam penelitian ini dengan menggunakan teknik probability sampling yaitu cluster sampling dengan prosedur pemilihan sampel menggunakan cara pengacakan gulungan kertas atau undian. Cluster sampling adalah teknik pengambilan sampel dengan melakukan randomisasi terhadap kelompok berdasarkan daerah, bukan terhadap subjek secara individual (Sugiyono, 2014).

\section{Tempat Penelitian}


Proses pengambilan sampel dilakukan di Kabupaten klungkung dan kabupaten gianyar. Penelitian dilaksanakan pada bulan Desember 2016.

\section{Alat Ukur}

Alat ukur yang digunakan dalam penelitian ini adalah 2 (dua) skala yaitu kecemasan dalam pemilihan pasangan dan skala pola asuh otoritarian. Skala kecemasan dalam pemilihan pasangan peneliti rancang sendiri berdasarkan pengelompokkan gejala-gejala cemas menjadi 3 dimensi menurut Hawari (2013), yaitu: gejala fisik, gejala afektif, dan gejala kognitif. Skala pola asuh otoritarian dimodifikasi menggunakan skala pola asuh otoritarian yang disusun oleh Dewi (2015). Kedua skala berupa skala likert yang digunakan untuk mengukur sikap, pendapat, dan persepsi seseorang atau sekelompok orang mengenai fenomena sosial dengan menggunakan empat pilihan jawaban, yaitu sangat setuju (SS), setuju (S), tidak setuju (TS), dan sangat tidak setuju (STS) (Sugiyono, 2015). Skala kecemasan dalam pemilihan pasangan dan skala pola asuh otoritarian disusun dalam bentuk pernyataan favorable dan unfavorable yang diberi skor mulai dari 1 sampai 4. Pada skala kecemasan dalam pemilihan pasangan dan skala pola asuh otoritarian terdapat 4 respon jawaban, yaitu sangat setuju (SS), setuju (S), tidak setuju (TS), dan sangat tidak setuju (STS). Pada pernyataan dalam aitem favorable jawaban sangat setuju (SS) diberi skor 4, setuju (S) diberi skor 3, tidak setuju (TS) diberi skor 2, dan sangat tidak setuju (STS) diberi skor 1. Sedangkan dalam pernyataan dalam aitem unfavorable jawaban sangat setuju (SS) diberi skor 1, setuju (S) diberi skor 2, tidak setuju (TS) diberi skor 3, dan sangat tidak setuju (STS) diberi skor 4.

Pada pengujian validitas skala kecemasan dalam pemilihan pasangan koefisien korelasi item total bergerak dari 0,392 sampai dengan 0,633. Hasil reliabilitas skala komitmen dengan menggunakan Cronbach Alpha adalah sebesar 0,908. Alpha $(\alpha)$ sebesar 0,908 menunjukkan bahwa skala ini mampu mencerminkan $90,80 \%$ variasi skor subjek adalah skor murni. Hasil tersebut menggambarkan skala kecemasan dalam pemilihan pasangan dapat digunakan untuk mengukur kecemasan dalam pemilihan pasangan.

Pada pengujian validitas skala pola asuh otoritarian koefisien korelasi item total bergerak dari 0,178 sampai dengan 0,703. Hasil reliabilitas skala intensitas komunikasi dengan menggunakan Cronbach Alpha adalah sebesar 0,912. Alpha $(\alpha)$ sebesar 0,912 menunujukkan bahwa skala ini mampu mencerminkan $91,20 \%$ variasi skor subjek adalah skor murni. Hasil tersebut menggambarkan skala pola asuh otoritarian dapat digunakan untuk mengukur pola asuh otoritarian.

\section{Teknik Analisis Data}

Metode analisis data yang digunakan dalam penelitian ini dengan menggunakan teknik Analysis Covariance (ANCOVA) dengan bantuan program analisis statistik SPSS versi 23.0. Analysis Covariance (ANCOVA) digunakan karena terdapat variabel bebas (bukan utama) metrik yang digunakan sebagai kovariat dalam model, yaitu variabel pola asuh otoritarian sehingga perlu untuk dikontrol pengaruhnya terhadap interaksi variabel bebas (variabel triwangsa) dan variabel tergantung (variabel kecemasan dalam pemilihan pasangan) (Ghozali, 2005). Analisis digunakan untuk mengetahui perbedaan antara rata-rata dua atau lebih kelompok dalam variabel bebas terhadap variabel tergantung dengan adanya kontrol terhadap variabel bebas (bukan utama) atau yang disebut dengan kovariat.

\section{HASIL PENELITIAN}

\section{Karakteristik Subyek}

Penelitian ini berhasil menganalisa data sejumlah 105 subjek. Data karakteristik subjek dalam penelitian ini dijelaskan menurut usia, kelompok wangsa, dan asal daerah subjek, yaitu sebagai berikut:

\section{a. Karakteristik Subjek Berdasarkan Usia}

Tabel 1.

\begin{tabular}{ccc}
$\begin{array}{c}\text { Deskripsi Subjek Berdasarkan Usia } \\
\text { Usia }\end{array}$ & Jumlah & \\
\hline 20 & 14 & Persentase \\
21 & 44 & $13,33 \%$ \\
22 & 14 & $13,90 \%$ \\
23 & 11 & $10,33 \%$ \\
24 & 14 & $13,33 \%$ \\
25 & 5 & $4,76 \%$ \\
27 & 3 & $2,86 \%$ \\
\hline Total & $\mathbf{1 0 5}$ & $\mathbf{1 0 0 \%}$
\end{tabular}

Hasil deskripsi subjek berdasarkan usia menunjukkan bahwa mayoritas subjek yang mengikuti penelitian ini berusia 21 tahun yang berjumlah 44 dengan persentase sebesar $41,90 \%$.

b. Karakteristik Subjek Berdasarkan Wangsa

Tabel 2.

Deskripsi Subjek Berdasarkan Wangs

\begin{tabular}{ccc}
\hline Deskripsi Subjek Berdasarkan Wangsa & & \\
\hline Usia & Jumlah & Persentase \\
\hline Brahmana & 35 & $33,33 \%$ \\
Ksatrya & 35 & $33,33 \%$ \\
Waisya & 35 & $33,33 \%$ \\
\hline Total & $\mathbf{1 0 5}$ & $\mathbf{1 0 0 \%}$
\end{tabular}

Hasil deskripsi subjek berdasarkan wangsa menunjukkan bahwa seluruh subjek berjumlah 35 dengan persentase yang sama sebesar 33, 33\%.

c. Karakteristik Subjek Berdasarkan Asal Daerah

Tabel 3.

Deskripsi Subjek Berdasarkan Asal Daerah

\begin{tabular}{ccc}
\hline Usia & Jumlah & Persentase \\
\hline Klungkung & 59 & $56,19 \%$ \\
Gianyar & 46 & $43,80 \%$ \\
\hline Total & $\mathbf{1 0 5}$ & $\mathbf{1 0 0 \%}$ \\
\hline
\end{tabular}

Hasil deskripsi subjek berdasarkan asal daerah menunjukkan bahwa mayoritas subjek yang mengikuti penelitian ini berasal dari Klungkung yang berjumlah 59 subjek dengan persentase sebesar $56,19 \%$ dan subjek 
yang berasal dari Gianyar berjumlah 46 subjek dengan persentase sebesar $43,80 \%$.

\section{Deskripsi Data Penelitian}

\begin{tabular}{lcc}
$\begin{array}{l}\text { Tabel } 4 . \\
\text { Deskripsi data penelitian }\end{array}$ & & \\
\hline Deskripsi Data & Pola Asuh Otoritarian & $\begin{array}{c}\text { Kecemasan dalam Pemilihan } \\
\text { Pasangan }\end{array}$ \\
\hline N & 105 & 105 \\
Mean Teoretis & 75 & 72.5 \\
Mean Empiris & 97,52 & 89,37 \\
SD Teoretis & 15 & 14,5 \\
SD Empiris & 4,899 & 4,479 \\
X min & 87 & 80 \\
X max & 113 & 102 \\
Sebaran Teoretis & $30-120$ & $29-116$ \\
Sebaran Empiris & $75-99$ & $80-102$ \\
\hline
\end{tabular}

\section{a. Pola asuh Otoritarian}

Hasil deskripsi statistik penelitian pada tabel 4 menunjukkan bahwa variabel pola asuh otoritarian memiliki mean teoretis sebesar 75 dan mean empiris sebesar 97,52 yang menghasilkan perbedaan sebesar 22,52. Hal ini menandakan bahwa subjek penelitian diasuh dengan pola asuh otoritarian yang tinggi karena nilai mean empiris lebih besar daripada mean teoretis $(97,52>75)$.

\section{b. Kecemasan dalam Pemilihan Pasangan}

Hasil deskripsi statistik penelitian pada tabel 4 menunjukkan bahwa variabel kecemasan dalam pemilihan pasangan memiliki mean teoretis sebesar 72,5 dan mean empiris sebesar 89,37 yang menghasilkan perbedaan sebesar 16,87. Hal ini menandakan bahwa subjek penelitian memilki tingkat kecemasan yang tinggi dalam pemilihan pasangan karena nilai mean empiris lebih besar daripada mean teoretis $(89,36>72,5)$.

\section{Kategorisasi Data Penelitiam}

Kategorisasi ini dilakukan untuk membedakan kategori dari masing-masing variabel, sehingga terlihat deskriptif kategori dari masing-masing variabel yang bersangkutan. Peneliti melakukan kategorisasi kedalam tiga kategori yaitu rendah, sedang, dan tinggi, dengan formula sebagai berikut :

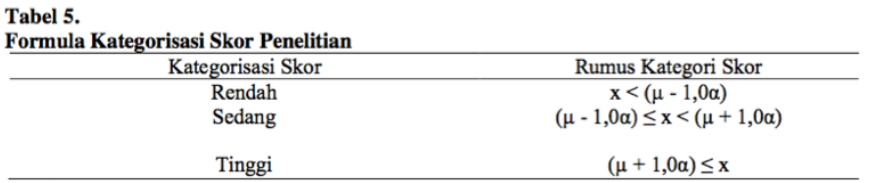

Berdasarkan formula kategorisasi tersebut, rincian kategorisasi skor variabel kecemasan beserta frekuensi dan persentasenya dicantumkan dalam tabel-tabel sebagai berikut:

\begin{tabular}{|c|c|c|c|}
\hline Rentang Nilai & Kategori & Jumlah & Persentase \\
\hline$X<60$ & Rendah & 0 & $0 \%$ \\
\hline $60 \leq X<90$ & Sedang & 7 & $6,67 \%$ \\
\hline $90 \leq X$ & Tinggi & 98 & $93,33 \%$ \\
\hline Total & & 105 & $100 \%$ \\
\hline
\end{tabular}

Berdasarkan kategorisasi skor pola asuh otoritarian diatas, menunjukkan bahwa tidak ada subjek yang diasuh dengan tingkat pola asuh otoritarian yang rendah. Sebanyak 7 subjek diasuh dengan tingkat pola asuh otoritarian yang sedang dengan persentase 6,67\%, dan sebanyak 98 subjek diasuh dengan tingkat pola asuh otoritarian tinggi dengan persentase $93,33 \%$, sehingga dalam hal ini menunjukkan bahwa mayoritas subjek diasuh dengan pola asuh otoritarian yang tinggi.

\begin{tabular}{|c|c|c|c|c|c|c|c|}
\hline $\begin{array}{c}\text { Rentang } \\
\text { Nilai }\end{array}$ & Kategori & Brahmana & Persentase & Ksatrya & Persentase & Waisya & Persentase \\
\hline$X<60$ & Rendah & 0 & $0 \%$ & 0 & $\%$ & & $\%$ \\
\hline $60 \leq X<90$ & Sedang & 4 & $11,43 \%$ & 2 & $5,72 \%$ & 1 & $2,86 \%$ \\
\hline $90 \leq X$ & Tinggi & 31 & $88,57 \%$ & 33 & $94,29 \%$ & 34 & $97,14 \%$ \\
\hline Total & & 35 & $100 \%$ & 35 & $100 \%$ & 35 & $100 \%$ \\
\hline
\end{tabular}

Kategorisasi skor pola asuh otoritarian berdasarkan kelompok wangsa, menunjukkan bahwa persentase yang paling besar pada kelompok wangsa Brahmana terletak pada kategori tinggi yaitu sebesar 88,57\%. Pada kelompok wangsa Ksatrya persentase terbesar terletak pada kategori tinggi yaitu sebesar 94,29\% dan pada kelompok wangsa Waisya persentase terbesar terletak pada kategori tinggi yaitu sebesar $97,14 \%$.

Tabel 8.

\begin{tabular}{cccc}
\multicolumn{4}{l}{ Kategorisasi Skor Kecemasan dalam Pemilihan Pasangan } \\
\hline Rentang Nilai & Kategori & Jumlah & Persentase \\
\hline$X<58$ & Rendah & 0 & $0 \%$ \\
$58 \leq X<87$ & Sedang & 30 & $28,57 \%$ \\
$87 \leq X$ & Tingi & 75 & $71,43 \%$ \\
\hline Total & & 105 & $100 \%$
\end{tabular}

Berdasarkan kategorisasi skor kecemasan dalam pemilihan pasangan diatas, menunjukkan bahwa tidak ada subjek yang memiliki tingkat kecemasan yang rendah dalam pemilihan pasangan. Sebanyak 30 subjek memiliki tingkat kecemasan yang sedang dalam pemilihan pasangan dengan persentase sebesar 28,57\%, sedangkan sebanyak 75 subjek memiliki tingkat kecemasan yang tinggi dalam pemilihan pasangan dengan persentase sebesar $71,43 \%$, sehingga dalam hal ini menunjukkan bahwa mayoritas subjek memiliki tingkat kecemasan yang tinggi.

Tabel 9.

Tabel 9.
\begin{tabular}{cccccccc}
\multicolumn{1}{l}{ Kategorisasi Skor Kecemasan dalam Pemilihan Pasangan berdasarkan Kelompok Wangsa } \\
$\begin{array}{c}\text { Rentang } \\
\text { Nilai }\end{array}$ & Kategori & Brahmana & Persentase & Ksatrya & Persentase & Waisya & Persentase \\
\hline X $<58$ & Rendah & 0 & $0 \%$ & 0 & $\%$ & 0 & $\%$ \\
$58 \leq \mathrm{X}<87$ & Sedang & 12 & $34,29 \%$ & 9 & $25,71 \%$ & 9 & $25,71 \%$ \\
$87 \leq \mathrm{X}$ & Tinggi & 23 & $65,72 \%$ & 26 & $74,29 \%$ & 26 & $74,29 \%$ \\
\hline Total & & 35 & $100 \%$ & 35 & $100 \%$ & 35 & $100 \%$ \\
\hline
\end{tabular}

Kategorisasi skor kecemasan dalam pemilihan pasangan berdasakan kelompok wangsa, menunjukkan bahwa persentase yang paling besar pada kelompok wangsa Brahmana terletak pada kategori tinggi yaitu sebesar $65,72 \%$. Pada kelompok wangsa Ksatrya dan wangsa Waisya memiliki persentase terbesar yang terletak pada kategori tinggi yaitu sebesar $74,29 \%$.

\section{Uji Asumsi}


Uji asumsi terlebih dahulu dilakukan, sebelum melakukan uji hipotesis yang meliputi uji normalitas, uji linieritas, sertauji homogenitas dengan bantuan program SPSS 23.0 for Windows. Hasil uji asumsi penelitian adalah sebagai berikut:

a. Uji Normalitas

Tabel 10.

Hasil Uji Normalitas Variabel Penelitia

\begin{tabular}{lcl}
\multicolumn{1}{c}{ Hasil Uji Normalitas Variabel Penelitian } & & \\
\hline \multicolumn{1}{c}{ Skala } & $\boldsymbol{P}$ & Kesimpulan \\
\hline Pola Asuh Otoritarian & 0,179 & Data Normal \\
Kecemasan dalam Pemilihan & 0,074 & Data Normal \\
Pasangan & &
\end{tabular}

Pasangan

Berdasarkan hasil uji normalitas data pada tabel 9, variabel pola asuh otoritarian dan variabel kecemasan dalam pemilihan pasangan berdistribusi normal karena nilai signifikansi lebih besar dari 0,05.

b. Uji Linieritas

Tabel 11.

\begin{tabular}{lcccc} 
Hasil Uji Linieritas Variabel Penelitian & $F$ & Sig & $\begin{array}{c}\text { Deviation } \\
\text { from } \\
\text { Linearity }\end{array}$ & Kesimpulan \\
& $F$ & 0,000 & 0,253 & Linier \\
\hline $\begin{array}{l}\text { Kecemasan dalam Pemilihan } \\
\begin{array}{l}\text { Pasangan*Pola Asuh } \\
\text { Otoritarian }\end{array}\end{array}$ & 1,228 & & &
\end{tabular}

Berdasarkan hasil uji linieritas data pada tabel 11, variabel pola asuh otoritarian dan variabel kecemasan dalam pemilihan pasangan memiliki hubungan yang linier karena nilai signifikansi kurang dari 0,05 dan nilai deviation from linearity yang lebih besar dari 0,05 .

c. Uji Homogenitias

\section{Tabel 12.}

\begin{tabular}{ccc}
\multicolumn{2}{l}{ Hasil Uji Homogenitas Variabel Penelitian } & \\
\hline Variabel & Sig & Kesimpulan \\
\hline $\begin{array}{c}\text { Kecemasan dalam Pemilihan } \\
\text { Pasangan *Pola Asuh } \\
\text { Otoritarian }\end{array}$ & 0,161 & Homogen \\
\hline
\end{tabular}

Tabel 13.

Levene's Test of Equality of Error Variances

Dependent Variabel: Kecemasan dalam Pemilihan Pasangan

$\begin{array}{lrrrr}\text { F } & \text { df1 } & \text { df2 } & \text { Sig. } \\ 1.408 & 2 & 102 & .249\end{array}$

Berdasarkan hasil uji homogenitas data pada tabel 12, variabel pola asuh otoritarian dan variabel kecemasan dalam pemilihan pasangan memiliki varians yang homogen karena nilai signifikansi lebih besar dari 0,05.

Selain itu uji homogenitas juga diperkuat dengan menggunakan Levene's Test of Equality of Error Variancesa pada tabel 13 tersebut, terlihat bahwa nilai signifikansi homogenitas tetap menunjukkan signifikansi yang lebih besar dari 0,05 yaitu sebesar 0,249. Hal tersebut menunjukkan bahwa varians data dalam penelitian ini memang homogen.
Pada penelitian ini akan dilakukan uji hipotesis dengan menggunakan teknik analisis regresi sederhana.

\section{a. Uji Hipotesis Mayor}

Analysis Covariance dilakukan dalam penelitian ini bertujuan untuk melihat perbedaan variabel tergantung yang ditinjau dari variabel bebas dengan adanya kontrol terhadap variabel bebas lain yang biasa disebut dengan kovariat. Hasil uji ANCOVA dapat dilihat pada tabel 14, sebagai berikut:

\begin{tabular}{|c|c|c|c|c|c|}
\hline \multicolumn{6}{|c|}{$\begin{array}{l}\text { Tabel } 14 . \\
\text { Hasil Uji Hipotesis Mayor } \\
\text { (adanya kontrol terhadap kovariat) } \\
\text { Tests of Between-Subjects Effects } \\
\text { Dependent Variabel: Kecemasan dalam Pemilihan Pasangan }\end{array}$} \\
\hline Source & $\begin{array}{l}\text { Type III Sum of } \\
\text { Squares }\end{array}$ & $D f$ & Mean Square & $F$ & Sig. \\
\hline $\begin{array}{l}\text { Corrected } \\
\text { Model }\end{array}$ & $372.249 \mathrm{a}$ & 3 & 124.083 & 7.311 & .000 \\
\hline Intercept & 630.512 & 1 & 630.512 & 37.148 & .000 \\
\hline PLO & 360.763 & 1 & 360.763 & 21.255 & .000 \\
\hline WNG & 31.274 & 2 & 15.637 & .921 & .401 \\
\hline Error & 1714.266 & 101 & 16.973 & & \\
\hline Total & 840748.000 & 105 & & & \\
\hline $\begin{array}{l}\text { Corrected } \\
\text { Total }\end{array}$ & 2086.514 & 104 & & & \\
\hline
\end{tabular}

Hasil uji dari hipotesa yang diajukan dalam penelitian ini dapat dilihat pada tabel Tests of Between-Subjects Effects. Pada tabel tersebut terdapat nilai corrected model yang merupakan nilai pengaruh semua variabel independen secara simultan atau bersama-sama terhadap variabel dependen. Artinya, nilai corrected model pada tabel 14 adalah nilai pengaruh dari variabel triwangsa dan pola asuh otoritatian secara bersama-sama terhadap kecemasan dalam pemilihan pasangan. Pada tabel 22, nilai signifikansi pada corrected model adalah sebesar $\mathrm{p}=$ 0,000 ( $\mathrm{p}<0,05$ ), sehingga kesimpulan yang diperoleh adalah H0 di tolak dan Ha diterima. Hasil tersebut menunjukkan bahwa pola asuh otoritatrian dan triwangsa memberikan kontribusi terhadap tingkat kecemasan dalam pemilihan pasangan pada wanita triwangsa.

Perbedaan juga dapat dilihat pada nilai adjusted $\mathrm{R}$ squared antara dilakukan dan tidak dilakukannya kontrol pada pola asuh otoritarian. Pada saat tidak dilakukan kontrol pada pola asuh otoritarian, nilai adjusted $\mathrm{R}$ squared kecemasan dalam pemilihan pasangan jika ditinjau dari triwangsa saja memiliki nilai sebesar -0,014. Nilai tersebut berarti bahwa variabel kecemasan dalam pemilihan pasangan hanya dapat dijelaskan oleh variabel triwangsa sebesar $-1,4 \%$, setelah dilakukan kontrol pada pola asuh otoritarian terjadi kenaikan nilai adjusted $\mathrm{R}$ squared menjadi 0,154. Nilai tersebut berarti bahwa variabel kecemasan dalam pemilihan pasangan dapat dijelaskan oleh variabel triwangsa dan pola asuh otoritarian sebesar $15,4 \%$. Adanya kenaikan sebesar

\section{Uji Hipotesis}


$16,8 \%$ tersebut menandakan bahwa model menjadi lebih baik setelah dilakukan kontrol pada pola asuh otoritarian. Berikut tabel 15 uji ANOVA tanpa adanya kontrol terhadap pola asuh otoritarian.

\begin{tabular}{|c|c|c|c|c|c|}
\hline Source & $\begin{array}{l}\text { Type III Sum of } \\
\text { Squares }\end{array}$ & $\mathrm{df}$ & Mean Square & $\mathrm{F}$ & Sig. \\
\hline Corrected Model & $11.486^{\mathrm{a}}$ & 2 & 5.743 & .282 & .755 \\
\hline Intercept & 838661.486 & 1 & 838661.486 & 41225.202 & .000 \\
\hline WNG & 11.486 & 2 & 5.743 & .282 & .755 \\
\hline Error & 2075.029 & 102 & 20.343 & & \\
\hline Total & 840748.000 & 105 & & & \\
\hline Corrected Total & 2086.514 & 104 & & & \\
\hline
\end{tabular}

\section{b. Uji Hipotesis Minor}

Pengujian hipotesis minor dilakukan untuk melihat variabel pola asuh otoritarian ditinjau dari triwangsa. Hal ini bertujuan untuk mengetahui apakah ada perbedaan pola asuh otoritarian antara wangsa Brahmana, wangsa Ksatrya, dan wangsa Waisya. Disamping itu, dalam penelitian ini juga ingin mengetahui bagaimana peran pola asuh otoritarian terhadap kecemasan dalam pemilihan pasangan pada wanita triwangsa.

Pengujian hipotesis minor yang pertama adalah uji beda variabel pola asuh otoritarian ditinjau berdasarkan wangsa Brahmana, wangsa Ksatrya, dan wangsa Waisya. Sebelum melakukan uji beda, akan dipertegas terlebih dahulu bahwa hasil uji normalitas pada variabel pola asuh otoritarian menunjukkan angka 0,602 (p>0,05), sehingga menyebabkan data berdistribusi normal. Pada uji varians atau homogen, variabel pola asuh otoritarian menunjukkan angka 0,524 ( $>>0,05)$ yang berarti bahwa varians data pola asuh otoritarian tersebut homogen. Oleh karena syarat normalitas dan homogenitas terpenuhi, maka uji beda dapat dilakukan. Analisis yang digunakan untuk melihat perbedaan ini adalah uji ANOVA karena data triwangsa memiliki 3 kategori di dalamnya. Hasil uji ANOVA dapat dilihat pada tabel 16.

\section{Tabel 16.}

Hasil Uji Anova (1)

ANOVA

\begin{tabular}{|c|c|c|c|c|c|}
\hline & Sum of Squares & $\mathrm{Df}$ & Mean Square & $\mathrm{F}$ & Sig. \\
\hline Between Groups & 176.933 & 2 & 88.467 & 3.891 & .024 \\
\hline Within Groups & 2319.257 & 102 & 22.738 & & \\
\hline Total & 2496.190 & 104 & & & \\
\hline
\end{tabular}

Pengambilan keputusan pada uji ANOVA didasarkan pada nilai signifikansi. Jika nilai $(\mathrm{p}>0,05)$, maka data yang diuji tidak memiliki perbedaan yang signifikan, begitu juga sebaliknya. Hasil dari uji ANOVA memperoleh nilai signifikansi yang menunjukkan bahwa $(p<0,05)$ yaitu 0,024 . Kesimpulan yang dapat diperoleh adalah terdapat perbedaan yang signifikan pada variabel pola asuh otoritarian jika ditinjau dari triwangsa.
Perbedaan nilai rata-rata pola asuh otoritarian jika ditinjau dari triwangsa dapat dilihat pada tabel 16.

\begin{tabular}{|c|c|c|c|c|c|c|}
\hline \multirow[t]{2}{*}{ (I) Wangsa } & \multirow[t]{2}{*}{ (J) Wangsa } & \multirow{2}{*}{$\begin{array}{l}\text { Mean Difference } \\
\text { (I-J) }\end{array}$} & \multirow[t]{2}{*}{ Std. Error } & \multirow[t]{2}{*}{ Sig. } & \multicolumn{2}{|c|}{$95 \%$ Confidence Interval } \\
\hline & & & & & Lower Bound & $\begin{array}{l}\text { Upper } \\
\text { Bound }\end{array}$ \\
\hline \multirow{2}{*}{ Brahmana } & Ksatrya & -.429 & 1.140 & .708 & -2.69 & 1.83 \\
\hline & Waisya & $-2.943^{\circ}$ & 1.140 & .011 & -5.20 & -.68 \\
\hline \multirow{2}{*}{ Ksatrya } & Brahmana & .429. & 1.140 & .708 & -1.83 & 2.69 \\
\hline & Waisya & $-2.514^{\circ}$ & 1.140 & .030 & -4.78 & -.25 \\
\hline \multirow{2}{*}{ Waisya } & Brahmana & $2.943^{\circ}$ & 1.140 & .011 & .68 & 5.20 \\
\hline & Ksatrya & $2.514^{\circ}$ & 1.140 & .030 & .25 & 4.78 \\
\hline
\end{tabular}

Berdasarkan tabel 16, dapat diketahui bahwa nilai signifikansi 0,708 ( $\mathrm{p}>0,05)$ menunjukkan bahwa pola asuh otoritarian tidak memiliki perbedaan jika ditinjau dari wangsa Brahmana dengan wangsa Ksatrya begitu juga sebaliknya.

Pengujian hipotesis minor kedua adalah dengan melakukan uji regresi sederhana pada variabel pola asuh otoritarian terhadap kecemasan dalam pemilihan pasangan. Hasil uji normalitas pada kedua variabel menunjukkan sebaran data yang bedistribusi secara normal yaitu $\mathrm{p}=0,179 \quad(\mathrm{p}>0,05)$ untuk signifikansi normalitas variabel pola asuh otoritarian dan $\mathrm{p}=0,074$ ( $>0,05)$ untuk signifikansi normalitas variabel kecemasan dalam pemilihan pasangan. Uji liniertias yang dilakukan sebelumnya juga menunjukkan nilai signifikansi sebesar $0,000(\mathrm{p}<0,05)$ dan nilai deviation from linearity sebesar $0,253(\mathrm{p}>0,05)$ yang berarti bahwa variabel kecemasan dalam pemilihan pasangan memiliki hubungan yang linier terhadap variabel pola asuh otoritarian, sehingga dengan data yang berdistribusi normal dan liniernya data tersebut, maka analisis data regresi sederhana dapat dilakukan. Hasil uji regresi sederhana dapat dilihat pada tabel 17.

Tabel 17.

\begin{tabular}{ccccc}
\multicolumn{3}{l}{ Hasil Uji Regresi Sederhana (1) } \\
R & R Square & $\begin{array}{c}\text { Std. Error of the } \\
\text { Estimate }\end{array}$ & F & Sig. \\
\hline $.404^{\mathrm{a}}$ & .163 & 4.117 & 20.120 & $.000^{\mathrm{b}}$ \\
\hline
\end{tabular}

Pada tabel 27 dapat dilihat bahwa koefisien regresi antara kecemasan dengan pola asuh otoritarian sebesar 0,404 dengan $\mathrm{R}$ square sebesar 0,163 yang memiliki arti bahwa variabel pola asuh otoritarian dapat menjelaskan variabel kecemasan sebesar 16,3\%. Nilai signifikansi $0,000(\mathrm{p}<0,05)$ menunjukkan bahwa pola asuh otoritarian berperan terhadap kecemasan dalam pemilihan pasangan pada wanita triwangsa. 
Tabel 18.

Hasil Uji Regresi Sederhana (2)

\begin{tabular}{|c|c|c|c|c|c|}
\hline \multirow[t]{3}{*}{ Model } & \multicolumn{2}{|c|}{ Unstandardized Coefficients } & \multirow{3}{*}{$\begin{array}{c}\begin{array}{c}\text { Standardized } \\
\text { Coefficients }\end{array} \\
\text { Beta }\end{array}$} & \multirow[t]{3}{*}{$\mathrm{T}$} & \multirow[t]{3}{*}{ Sig. } \\
\hline & & & & & \\
\hline & B & Std. Error & & & \\
\hline (Constant) & 53.327 & 8.046 & & 6.628 & .000 \\
\hline $\begin{array}{l}\text { Pola Asuh } \\
\text { Otoritarian }\end{array}$ & .370 & .082 & .404 & 4.486 & .000 \\
\hline
\end{tabular}

Tabel 18 menunjukkan interpretasi terhadap koefisien dari variabel bebas yang dilihat pada unstandardized coefficients. Dapat dilihat bahwa variabel pola asuh otoritarian memiliki nilai signifikansi $0,000(\mathrm{p}<0,05)$, sehingga dari tabel diatas dapat disimpulkan bahwa variabel pola asuh otoritarian memiliki hubungan fungsional terhadap variabel kecemasan.

\section{PEMBAHASAN DAN KESIMPULAN}

Hasil Analysis Covariance menunjukkan bahwa terdapat perbedaan tingkat kecemasan dalam pemilihan pasangan pada wanita triwangsa apabila ditinjau berdasarkan pola asuh otoritarian. Hasil pengolahan data menunjukkan signifikansi sebesar $0,000(\mathrm{p}<0,05)$ dan dengan nilai $\mathrm{F}$ test sebesar 7.311, sehingga H0 yang menyatakan "tidak ada perbedaan tingkat kecemasan dalam pemilihan pasangan pada wanita triwangsa yang ditinjau berdasarkan pola asuh otoritarian" tidak terbukti, sedangkan Ha yang menyatakan "terdapat perbedaan tingkat kecemasan dalam pemilihan pasangan pada wanita triwangsa dengan adanya kontrol dari pola asuh otoritarian" terbukti.

Nilai koefisien korelasi yang bernilai positif menunjukkan bahwa terdapat perbedaan yang searah antar kedua varibel. Hubungan searah ini dapat diartikan bahwa apabila terjadi peningkatan pada pola asuh otoritarian maka tingkat kecemasan dalam pemilihan pasangan juga akan meningkat. Sebaliknya, apabila terjadi penurunan pola asuh otoritarian maka tingkat kecemasan dalam pemilihan pasangan akan menurun. Perbedaan tingkat kecemasan dalam pemilihan pasangan tersebut juga diperkuat ketika dilakukan uji ANOVA. Sebelum dikontrol oleh pola asuh otoritarian, tingkat kecemasan dalam pemilihan pasangan memiliki nilai Adjusted R squared sebesar -0,014. Setelah dikontrol oleh variabel pola asuh otoritarian, terdapat peningkatan nilai tingkat kecemasan dalam pemilihan pasangan menjadi 0,154 , sehingga terbukti bahwa pola asuh otoritarian lebih berperan dibanding wangsa terhadap kecemasan dalam pemilihan pasangan pada wanita triwangsa.

Munculnya kecemasan dalam pemilihan pasangan memiliki dampak bagi seseorang, khususnya pada wanita triwangsa. Menurut Kecemasan dalam diri seseorang dapat menimbulkan dampak yang berpengaruh pada suasana hati (mood), pikiran atau koginitif, dan pada perilaku atau motorik. Jika dikaitkan dengan penelitian ini, maka munculnya kecemasan dalam diri wanita triwangsa dapat memberikan dampak pada suasana hati (mood), pikiran atau koginitif, dan pada perilaku atau motorik wanita triwangsa itu sendiri. Dilihat dari suasana hati (mood), adanya kecemasan dalam pemilihan pasangan akan menyebabkan wanita triwangsa memiliki perasaan akan adanya hukuman dari orangtua maupun keluarga apabila tidak memilih pasangan dari wangsa yang sepadan. Kecemasan juga dapat berdampak pada pikiran atau kognisi wanita triwangsa seperti adanya kekhawatiran pada wanita triwangsa itu sendiri mengenai hal yang tidak menyenangkan yang mungkin akan terjadi di kemudian hari jika wanita triwangsa tersebut memilih pasangan dari wangsa yang tidak sepadan. Dampak terakhir yang dapat ditimbulkan dari adanya kecemasan dalam pemilihan pasangan adalah dampak pada motorik atau perilaku dari wanita triwangsa, seperti sering gugup dan menjadi tidak tenang (Semiun dalam Agita, 2012).

Bagi masyarakat Hindu permasalahan pernikahan (wiwaha) mempunyai arti dan kedudukan yang khusus dalam dunia kehidupan masyarakatnya (Rudita, 2015). Hal tersebut menyebabkan pemilihan pasangan merupakan salah satu keputusan terpenting yang harus menjadi pertimbangan bagi wanita, khususnya wanita triwangsa. Wanita triwangsa harus mempertimbangkan banyak hal seperti mempertimbangkan memilih pasangan dari wangsa yang lebih rendah. Apabila wanita menikah dengan wangsa yang lebih rendah secara otomatis wanita triwangsa akan kehilangan status triwangsanya. Menikah dengan wangsa yang lebih rendah hingga saat ini masih dihindari, walaupun secara normatif larangan perkawinan beda wangsa telah dihapus melalui keputusan DPRD Bali Nomor 11 Tahun 1995, akan tetapi secara sosiologis masih menunjukkan bahwa sampai saat ini larangan tersebut masih membekas (Sudantra, 2007).

Faktor pemilihan pasangan pada wanita triwangsa di Bali erat kaitannya dengan latar belakang keluarga, seperti pernikahan antar ras dan suku masih menjadi masalah dalam masyarakat Bali karena membentuk sebuah keluarga pada wanita triwangsa tidak semata-mata hanya mempertimbangkan keputusan pribadi ataupun keputusan dengan pasangan. Wanita triwangsa akan terikat dengan tatanan wangsa yang diajarkan untuk memilih pasangan dengan wangsa yang sepadan. Masalah akan cenderung terjadi bukan pada pasangan tetapi pada keluarga, kerabat, dan masyarakat sekitar (Degenova, 2008). Hal tersebut juga memiliki kemiripan makna dengan Kitab Manawa Dharmasastra yang menyatakan bahwa pada dasarnya sebuah pernikahan hendaknya dilaksanakan antara orang-orang yang memiliki wangsa yang sepadan, karena pernikahan akan memengaruhi keturunan atau anak-anak yang akan dilahirkan dari pernikahan itu sendiri (Dewi, 2013). 
Wanita triwangsa harus mempertimbangkan restu dari orangtua yang merupakan hal terpenting dalam keputusan untuk memilih pasangan, karena restu orangtua akan memengaruhi terciptanya hubungan yang bahagia (Adi, 2016). Umumnya, agar proses pernikahan direstui oleh orangtua, wanita triwangsa mendapatkan tuntutan dari pihak keluarga untuk melestarikan wangsanya, karena sistem sosial masyarakat Hindu di Bali terkait dengan wangsa masih memiliki pengaruh yang signifikan, khususnya dalam pernikahan (Winarta, 2015).

Pertimbangan-pertimbangan dalam pemilihan pasangan diatas dapat memengaruhi individu dalam melangsungkan kehidupannya, seperti merasa cemas apabila tidak sesuai dengan apa yang diharapkan keluarga untuk melestarikan wangsa. Mekanisme kecemasan terjadi ketika seseorang mengalami stressor psikososial seperti perkawinan, orangtua, antar pribadi, pekerjaan, lingkungan, keuangan, hukum, perkembangan, penyakit fisik, faktor keluarga, dan trauma (Hawari, 2013). Kecemasan juga dapat disebabkan oleh faktor predisposisi dan faktor presipitasi (Stuart, 2006). Faktor predisposisi adalah faktor individu yang sudah ada sebelum merasa cemas, seperti pengetahuan, sikap dan kepercayaan. Jika dikaitkan pada penelitian ini, maka faktor predesposisi muncul ketika wanita triwangsa diberi pengetahuan, ajaran, dan kepercayaan mengenai wangsa.

Memberikan ajaran mengenai wangsa, serta menerapkan nilai-nilai yang berlaku sebagai wanita dalam kategori triwangsa membuat para orangtua dari kategori triwangsa akan memberikan kontrol yang berlebihan untuk mengarahkan anaknya agar sesuai dengan nilai-nilai yang berlaku. Agar wanita triwangsa berlaku sesuai dengan arahan yang diberikan, orangtua akan mengambil kendali yang tegas serta menetapkan batasan-batasan untuk memilih pasangan dari wangsa yang sepadan atau lebih tinggi, yang dapat disalurkan melalui pola asuh. Pola asuh merupakan cara yang dilakukan oleh orangtua dalam memberikan aturan-aturan dengan tujuan mendidik anak, memberikan anak perhatian, membimbing, dan melindungi anak serta mentransfer nilainilai dan keyakinan (Baumrind dalam Santrock 2007a).

Peran orangtua dalam keluarga sangat memberikan pengaruh yang kuat terhadap anak-anaknya, pengalamanpengalaman yang lebih dulu dirasakan orangtua menyebabkan orangtua dari kategori triwangsa meyakini bahwa pola asuh otoritarian merupakan salah satu pola asuh yang terbaik agar ajaran yang diterapkan sesuai dengan apa yang diharapkan oleh orangtua. Harapan yang tinggi dari orangtua merupakan salah satu faktor penyebab timbulnya pola asuh otoritarian. Orangtua mendidik anak tidak hanya berharap agar anaknya mampu memilih hal-hal yang baik dan buruk namun juga berharap jika anak pada akhirnya nanti bisa hidup bahagia (Muhli dalam Tis'Ina \& Suroso, 2015). Terkadang orangtua sampai memaksakan diri agar anak dari kategori triwangsa bisa mencapai harapan seperti apa yang diinginkan oleh orangtua termasuk dalam pemilihan pasangan, sehingga dalam hal memilih pasangan orangtua dari kategori triwangsa akan mengambil kendali atas keputusan yang akan diambil.

Tingginya pola asuh otoritarian yang diterapkan pada anak dari kategori triwangsa, dapat memicu tingginya kecenderungan homogamy dalam memilih pasangan. Teori pemilihan pasangan homogamy adalah kecenderungan memilih pasangan yang memiliki kesamaan atribut atau kualitas diri seperti latar belakang keluarga dan karakteristik personal dirinya, yang dalam penelitian ini difokuskan pada kesepadanan wangsa (Alit \& Lestari, 2014). Selain adanya teori pemilihan pasangan secara homogamy, terdapat teori endogamy yang berarti memilih pasangan dari dalam kelompok yang sama, seperti misalnya kelompok berdasarkan wangsa. Kelompok berdasarkan wangsa dilihat dari norma yang berada didalam masyarakat, biasanya norma pada masyarakat atau kelompok tertentu memiliki kiteria tertentu yang lebih diunggulkan dan diutamakan, misalnya memilih pasangan dari wangsa yang sama atau sepadan.

Berdasarkan hal tersebut, tidak dipungkiri bahwa orang dengan status triwangsa lebih mementingkan garis keturunan dan status dibandingkan cinta dan kasih sayang (Bhopal dalam Olson \& Defrain, 2003). Hal ini didukung oleh penelitian Kalmijn (1998) yang menyatakan bahwa seseorang akan memiliki kecenderungan untuk menikah dengan intern kelompok sosial individu tersebut atau seseorang yang memiliki kedekatan status dengan individu tersebut.

Selain faktor predesposisi, faktor lainnya seperti faktor presipitasi yang merupakan faktor pencetus terjadinya suatu masalah. Faktor presipitasi terdiri dari faktor eksternal dan internal yang salah satunya dapat membahayakan identitas, harga diri, serta fungsi sosial pada individu (Stuart, 2006). Wanita triwangsa meyakini bahwa dengan menuruti apa yang menjadi harapan orangtua untuk memilih pasangan dari wangsa yang sepadan merupakan suatu perbuatan baik yang harus dilakukan, namun apabila wanita triwangsa yang memiliki pasangan dari wangsa yang lebih rendah, wanita triwangsa tidak hanya menentang apa yang diajarkan orangtua, tetapi juga berpengaruh pada faktor presipitasi yang dapat membahayakan identitas, harga diri sebagai wanita triwangsa.

Faktor presipitasi tersebut dapat berupa sanksi-sanksi yang dapat menimbulkan permasalahan psikologis bagi wanita triwangsa, seperti sakit, cemas, sedih, serta adanya rasa bersalah. Sanksi yang diberikan dapat juga berupa perlakuan diskriminatif seperti tidak diijinkan makan bersama dengan orangtua atau bahkan keluarga besar dari wanita triwangsa dan biasanya tidak akan diizinkan pulang kerumah asal, namun ada beberapa yang mengijinkan untuk pulang kerumah asal untuk menghadiri suatu upacara dari keluarga dari wanita triwangsa, disini akan terlihat jelas dari bahasa yang 
digunakan yang mengharuskan wanita triwangsa untuk menggunakan bahasa halus (sor singgih) dalam berbicara dengan orangtua, saudara atau kerabatnya di keluarga asal (Dewi, 2013).

Penjelasan diatas menunjukkan bahwa perbedaan kecemasan yang dirasakan pada wanita triwangsa sangat beragam, yang dipengaruhi oleh faktor-faktor tertentu baik faktor predesposisi atau faktor presipitasi yang dikaitkan dengan faktor internal maupun eksternal dari wanita triwangsa. Rasa cemas pada wanita triwangsa akan semakin tinggi apabila orangtua dari wanita triwangsa tersebut menerapkan pola asuh otoritarian yang ditandai dengan adanya kontrol yang tinggi terhadap anak. Sejalan dengan penelitian (pasangan (Berk dalam Prayoga, 2013), yang menyatakan bahwa anak dengan pola asuh otoritarian akan cenderung menggambarkan kecemasan dan didukung juga oleh uji regresi sederhana yang menyatakan bahwa pola asuh otoritarian berperan terhadap kecemasan dalam pemilihan pasangan. Pola asuh otoritarian dapat menyebabkan kecemasan dalam pemilihan pasangan karena pola asuh otoritarian menjadikan anak cenderung dituntut oleh orangtua dalam bidang apapun sehingga memunculkan kecemasan, kekhawatiran, dan ketidakberartian anak jika tidak bisa memenuhi harapan orangtua. Begitu juga pada wanita triwangsa yang diberikan tuntutan oleh orangtua untuk memilih pasangan yang berwangsa sepadan, sehingga akan timbul kecemasan apabila wanita triwangsa tersebut tidak memilih pasangan dari wangsa yang sepadan.

Penerapan pola asuh otoritarian ini juga diperkuat dengan kategorisasi pada setiap kelompok wangsa yang memperoleh hasil bahwa orangtua yang menerapkan pola asuh otoriatrian tidak ada yang berada pada kategori tingkat rendah. Pola asuh yang diterapkan oleh orangtua dari setiap kelompok kategori triwangsa memperoleh kategori pada tingkat sedang dan tinggi. Adanya perbedaan kategori pola asuh yang diterapkan oleh orangtua dari setiap kelompok kategori triwangsa didukung oleh uji hipotesis minor yang menyatakan bahwa terdapat perbedaan pola asuh otoritarian jika ditinjau dari triwangsa. Artinya, masing-masing wangsa memiliki tingkat penerapan pola asuh otoritarian yang berbeda, namun peneliti hingga saat ini belum menemukan hal apa saja yang membedakan penerapan pola asuh otoritarian dari masingmasing wangsa.

Berdasarkan hal tersebut, melalui prosedur penelitian dan analisis data yang sesuai, penelitian ini dapat dikatakan mampu mencapai tujuannya, yaitu mampu mengetahui perbedaan tingkat kecemasan dalam pemilihan pasangan pada wanita triwangsa ditinjau dari pola asuh otoritarian.

Adapun kesimpulan dalam penelitian ini yaitu diantaranya pertama, ada perbedaan tingkat kecemasan dalam pemilihan pasangan pada wanita triwangsa ditinjau berdasarkan pola asuh otoritarian. Kedua, terdapat perbedaan pola asuh otoritarian yang diterapkan pada wanita triwangsa. Ketiga, analisis lebih lanjut menunjukkan perbedaan tersebut terjadi pada antara wangsa ksatrya dan wangsa waisya, serta wangsa brahmana dan wangsa waisya, namun tidak terjadi perbedaan pola asuh otoritarian antara wangsa brahmana dan wangsa ksatrya. Keempat, pola asuh otoritarian berperan terhadap kecemasan dalam pemilihan pasangan pada wanita triwangsa. Kelima, pola asuh otoritarian lebih berperan dibanding wangsa terhadap kecemasan dalam pemilihan pasangan pada wanita triwangsa.

Terdapat keterbatasan dalam penelitian ini, yaitu, (1) Hingga saat ini belum menemukan literatur yang membahas mengenai apa saja hal yang menjadi pembeda dari masing-masing kategori triwangsa yang menyebabkan adanya perbedaan tingkat penerapan pola asuh otoritarian yang ditinjau dari wangsa. (2) Penelitian ini tidak semua wanita triwangsa menjawab kuisioner dengan lengkap karena dipengaruhi faktor kekhawatiran yang berlebihan akan kerahasiaan data yang nantinya akan memengaruhi hubungan dengan pasangan atau keluarga khususnya orangtua. (3) Penelitian ini tidak melakukan perbandingan tingkat kecemasan dalam pemilihan pasangan antara kelompok Triwangsa dengan kelompok Jabawangsa.

Saran bagi peneliti selanjutnya yaitu (a) Dapat melakukan penelitian pada wanita triwangsa dewasa awal yang berada diluar Bali untuk melihat apakah terjadi hal yang sama pada wanita triwangsa dewasa awal di Bali khususnya dalam pemilihan pasangan. (b) Dapat melakukan penelitian untuk melihat perbandingan tingkat kecemasan dalam pemilihan pasangan antara kelompok Triwangsa dengan kelompok Jabawangsa. (c) Dapat menggunakan penelitian secara kualitatif untuk melihat secara mendalam faktor-faktor apa saja yang berpengaruh pada kecemasan dalam pemilihan pasangan, sehingga menghasilkan perbedaan pada tiap kelompok wangsa. (d) Berdasarkan konteks triwangsa, diharapkan untuk lebih memperbanyak literatur agar pertanyaan penelitian terjawab secara mendalam dan komprehensif.

\section{DAFTAR PUSTAKA}

Adi, I.A.R.P. (2016). Gambaran kecemasan pada wanita triwangsa yang menjalin hubungan dengan wangsa yang lebih rendah. Naskah Tidak Dipublikasikan. Program Studi Psikologi Fakultas Kedokteran Universitas Udayana. Denpasar.

Adi, I.A.R.P. (2016). Studi Pendahuluan: Pola asuh yang diterapkan orangtua pada wanita Triwangsa dalam Pemilihan Pasangan. Fakultas Kedokteran Universitas Udayana. Denpasar: Tidak dipublikasikan.

Agita, H.C. (2012). Kecemasan dalam menghadapi masa bebas pada narapidana anak di lembaga permasyarakatan anak Kutoarjo. Naskah Tidak Dipublikasikan. Universitas Negeri Yogyakarta. Yogyakarta. 
Alit, I.A \& Lestari, M.D. (2014). Hubungan pola asuh authoritative dengan kecenderungan homogamy dalam pemilihan pasangan pada wanita Bali dewasa awal Wangsa Brahmana di Denpasar. Jurnal Psikologi Udayana. 1(3).476-482.

Alwi, H. (2002). Kamus besar Bahasa Indonesia. Jakarta: Balai Pustaka.

Antara, I. G. P. (2013). Tata nama Orang Bali. Denpasar: Buku Arti.

Angelina, D.Y. \& Matulessy, A. (2013). Pola asuh otoriter, kontrol diri dan perilaku seks bebas remaja SMK. Jurnal Psikologi Indonesia, 2 (2).173-182.

Atkinson, R.L., Atkinson, R.C., \& Hilgard, E.R. (1983). Pengantar psikologi I. Jakarta: Erlangga.

Azwar, S. (2014). Reliabilitas dan validitas. Yogyakarta: Pustaka Belajar.

Cross, D.R. (2009, January 22). Parenting style. Retrieved April 12, 2016 , from: http://www.davidcross.us/classes/child/ParentingStyle.pdf.

Davison, G.C., Neale, J.M., \& Kring, A.M. (2004). Psikologi abnormal. Jakarta: PT RajaGrafindo Persada.

Degenova, M.K. (2008). Intimate relationship, marriges \& families. New York: The Me Graw-Hill Companies.

Delima, V.S (2013). Kecemasan memperoleh pasangan hidup pada wanita dewasa awal yang mengalami obesitas. Retrieved April 12, 2016, from: http://library.gunadarma.ac.id/repository/view/3762994/kec emasan-memperoleh-pasangan-hidup-pada-wanita-dewasaawal-yang-mengalami-obesitas.htm.

Dewi, I.A.M.L. (2013). Implikasi perkawinan beda kasta dalam perspektif hukum, sosial-budaya dan religius di Banjar Brahmana Bukit, Kecamatan Bangli, Kabupaten Bangli. Jurnal PPKn, 1 (6). 1-14.

Dewi, N.P.A.R. (2015). Hubungan antara kecenderungan pola asuh otoriter (authoritarian parenting style) dengan gejala perilaku agresif pada remaja. Naskah Tidak Dipublikasi, Program Studi Psikologi, Fakultas Kedokteran Universitas Udayana, Denpasar.

Diantha, P. \& Wisanjaya, E. (2010). Kasta dalam perspektif hukum dan HAM. Udayana University Press: CV. Bali Media Adhikarsa.

Ghozali, I. (2005). Aplikasi analisis multivariate dengan program SPSS. Semarang: Badan Penerbit Universitas Diponegoro.

Gunarsa, S.D. \& Gunarsa Y.S. (2000). Psikologi praktis: Anak, remaja dan keluarga. Jakarta: Gunung Mulia.

Hamidah, (2002). Perbedaan kepekaan sosial ditinjau berdasarkan persepsi remaja terhadap pola asuh orangtua pada remaja di Jawa Timur. Jurnal: Insan, 4 (3). 132-160.

Hawari, D. (2013). Manajemen stress cemas dan depresi. Jakarta: Badan Penerbit FKUI

Hardy, I.G.N.W., Setiawan, B., \& Prayitno, B. (2016). Pengaruh sistem catur wangsa terhadap perwujudan tata spasial kota peninggalan kerajaan Hindu di Bali: kasus Kota Karangasem. Jurnal Kajian Bali, 6 (2). 1-18.

Kalmijn, M. (1998). Annual review of sociology: Intermarriage and homogamy: Causes, patterns, trends. Proquest [On-line Series]. 24 (1). 395-451

Kenny, J. \& Kenny, M. (1991). Dari bayi sampai dewasa. Jakarta: PT BPK Gunung Mulia.

King, L.A. (2010). Psikologi umum sebuah pandangan apresiatif. Jakarta: Salemba Humanika.

Kompasiana, (2014). Mengenal sistem kekerabatan patrilineal dan matrilineal. Retrieved November 22, from: Kompasiana, (2014). Mengenal Sistem Kekerabatan Patrilineal dan Matrilineal. Retrieved November 22, from: http://www.kompasiana.com/honey95t/mengenal-sistemkekerabatan-patrilineal-danmatrilineal_54fd224fa33311043d50f8b.
Lestari, S. (2012). Psikologi keluarga : Penanaman nilai \& penanganan konflik dalam keluarga. edisi pertama. Jakarta: Kharisma Putra.

Mahardini, N.M.D. (2016). Perempuan Hindu Bali yang nyerod dalam melakukan penyesuaian diri. Naskah Tidak Dipublikasi, Program Studi Psikologi, Fakultas Kedokteran Universitas Udayana, Denpasar.

Nevid, J.S., Ratus, S.A., \& Greene, B. (2005). Psikologi abnormal. edisi kelima. Jakarta: Airlangga.

Olson, D.H \& DeFrain, J. (2003). Marriages and families: Intimacy, strengths and diversity (ed-4). New York: McGraw-Hill.

Panetje, G. (2004). Aneka catatan tentang Hukum Adat Bali. Denpasar: CV Kayumas.

Paramitha, I.A.P. \& Susilawati, L.K.P (2016). Resiliensi perempuan janda nyerod yang pernah mulih deha. Naskah Tidak Dipublikasi, Program Studi Psikologi, Fakultas Kedokteran Universitas Udayan, Denpasar.

Purnomo, I. M. D. H., Natajaya, I.N., \& Sudiatmika, K. (2014). Pelaksanaan perkawinan beda kasta di Banjar Dauhwaru, Kecamatan Jembrana, Kabupaten Jembrana. Naskah Tidak Dipublikasikan, Jurusan Pendidikan Pancasila dan Kewarganegaraan, Undiksha Singaraja.

Putra, I.D.G.U., dkk. (2013). Dinamika psikologis perempuan Bali triwangsa dalam pemilihan pasangan. Naskah Tidak Dipublikasikan, Program Studi Psikologi, Fakultas Kedokteran Universitas Udayana. Denpasar.

Prayoga, S.A. (2013). Pola pengasuhan anak pada keluarga orangtua tunggal. Naskah Tidak Dipublikasikan. Fakultas Ilmu Sosial Dan Politik, Universitas Lampung.

Rudita, I.M. (2015). Hak asasi manusia dan perkawinan Hindu. Jurnal advokasi, 5 (1), 1-16.

Santrock, J.W. (2007a). Perkembangan anak. Jakarka: PT Gramedia.

Santrock, J.W. (2007b). Remaja. edisi kesebelas. Jakarta: Erlanggga.

Santrock, J.W. (2009). Life span development (ed.12). New York: McGraw-Hill International.

Stuart. (2006). Buku saku keperawatan jiwa. edisi kelima. Jakarta: EGC.

Sudantra, I.K. (2007). Asupundung dan alangkahi hulu: ketidakadilan gender dalam sistem wangsa. Naskah Tidak Dipublikasikan, Fakultas Hukum Universitas Udayana, Denpasar.

Sugiyono. (2010). Metode penelitian bisnis. Bandung: Alfabeta.

Sugiyono. (2014). Metode penelitian kuantitatif, kualitatif, dan kombinasi (mixed methods). Bandung: Alfabeta.

Sugiyono. (2015). Metode penelitian kuantitatif kualitatif dan R\&D. Bandung: Alfabeta.

Tis'Ina, N.A \& Suroso, (2015). Pola asuh otoriter, konformitas dan perilaku school bullying. Jurnal Psikologi Indonesia, 4 (2). 153-161

Wiana, I.K. (2006). Memahami perbedaan catur varna, kasta dan wangsa. Surabaya: Penerbit Paramita.

Winarta, A.A.G. (2015). Eksistensi kasta dalam sistem sosial masyarakat Hindu di Kecamatan Toili Barat. Program Studi Pendidikan Sejarah Fakultas Ilmu Sosial, Universitas Negeri Gorontalo. 